Jacek Hadryś ${ }^{1}$

Uniwersytet im. Adama Mickiewicza w Poznaniu

Wydział Teologiczny

\title{
Modlitwa Jezusowa w teorii i praktyce
}

Promulgowany przez św. Jana Pawła II Katechizm Kościoła katolickiego stwierdza, iż Imieniem, które zawiera wszystko, jest właśnie imię, które Syn Boży otrzymuje w swoim Wcieleniu: JEZUS. Ludzkie wargi nie sq w stanie wypowiedzieć Boskiego Imienia, ale Słowo Boże, przyjmując nasze człowieczeństwo, powierza je nam i możemy go wzywać. Imię Jezus obejmuje wszystko: Boga i człowieka oraz całą ekonomię stworzenia i zbawienia ${ }^{2}$. Jednocześnie Katechizm dodaje, że można modlić się wymawiając to szczególne imię oraz określa sens takiej modlitwy: Modlić się mówiąc imię Jezus, oznacza wzywać Go, wołać do Niego w nas. Tylko Jego imię zawiera Obecność, która oznacza. Jezus jest Zmartwychwstatym i ktokolwiek wzywa Jego imienia, przyjmuje Syna Bożego, który go umiłowat i siebie samego wydat za niego ${ }^{3}$.

Celem niniejszego artykułu jest przedstawienie zagadnienia modlitwy Jezusowej zarówno od strony teoretycznej, jak i praktycznej. W związku z tym całość problematyki została podzielona na kilka części: wyjaśnienie pojęcia i zasadności tego rodzaju modlitwy, krótkie zaprezentowanie jej historii, przestawienie struktury, głównych elementów, etapów, praktyki i znaczenia dla życia duchowego. Opracowanie tematu zostało dokonane poprzez analizę, a następnie syntezę wybranych dokumentów Kościoła oraz publikacji dotyczących Imienia Jezus i modlitwy tymże Imieniem, wyszczególnionych w załączonej bibliografii.

\section{Pojęcie, zasadność i geneza modlitwy Jezusowej}

Modlitwa Jezusowa to praktyka powtarzania Imienia Jezus. Praktyka ta przybrała formę szerszej inwokacji o różnych formach: Panie, Jezu Chryste, Synu

${ }^{1}$ Ksiądz Jacek Hadryś, kapłan archidiecezji poznańskiej, profesor UAM; wykładowca teologii duchowości, kierownik Zakładu Teologii Moralnej, Duchowości i Katolickiej Nauki Społecznej; dyrektor Szkoły Katechistów Archidiecezji Poznańskiej; cenzor ksiąg religijnych.

${ }^{2}$ Katechizm Kościoła katolickiego, nr 2666, Poznań 2002.

3 Tamże. 
Boży, zmiluj się nade mna ${ }^{4}$. Panie, Jezu Chryste, Synu Boży, zmituj się nade mna grzesznikiem ${ }^{5}$. Jej istotą jest ciągłe wzywanie Jezusa za pośrednictwem krótkiej formuły, stanowiącej akt wiary i prośbę o miłosierdzie. Powtarzaniu tejże formuły towarzyszy świadomość stałej obecności Boga. Łączy się ona także z zachowaniem wewnętrznej czujności i uwagi, a niekiedy także ze specjalną techniką skupienia. Modlitwa Jezusowa jest zwana także modlitwą serca albo nieustanną modlitwą ${ }^{6}$. Istnieje również w formie maryjnej: Panie, Jezu Chryste, Synu Boży, przez modlitwy Twojej Przeczystej Matki i wszystkich świętych, zmiluj się nade mna grzesznikiem? ${ }^{7}$

Modlitwa Jezusowa od strony teologicznej jest głęboko zakorzeniona w Biblii. Imię w Piśmie Świętym wyraża głębię osoby, która je nosi, mówi o czynnej obecności tejże osoby. Poznać imię Boga oznacza znaleźć się w Jego obecności (por. Wj 3,13-16), wzywać imienia Boga to wchodzić $\mathrm{z}$ we wspólnotę z Bogiem. Można stwierdzić, że w imieniu Boga najważniejsze jest nieustanne i zbawcze bycie i działanie Boga dla człowieka. Z kolei imię Jezus w języku hebrajskim ma znaczenie: Jahwe jest zbawieniem. Wymawianie tegoż imienia wprowadza w sferę zbawczego oddziaływania Boga. Samo gromadzenie się w imię Jezusa zapewnia Jego obecność: Bo gdzie sa dwaj albo trzej zebrani $w$ imię moje, tam jestem pośród nich (Mt 18,20). Znamienne, że kiedy apostołowie wzywali imienia Jezusa, to dokonywali cudów (por. Dz 4,30), leczyli chorych (por. Dz 3,6; 9,34), usuwali zło (por. Mk 9,38). Można uważać, że według Biblii wzywanie Imienia Jezusa uobecnia Jego Osobę, jednoczy z Nim oraz wprowadza w krąg Jego zbawczych mocy, które chronią od zła i zapewnia skuteczność Jego mocy9.

Zasadność samej modlitwy Jezusowej wynika z nauczania Chrystusa. Za główne uzasadnienie uważa się kilka tekstów biblijnych. Pierwszym z nich jest przykazanie miłości Boga, gdyż ciągłe myślenie o Bogu stanowi wyraz miłości do Niego oraz potwierdzenie zjednoczenia $\mathrm{z} \mathrm{Nim}{ }^{10}$. Kolejnym tekstem jest bezpośrednie polecenie Chrystusa dotyczące nieustannej modlitwy: Powiedział im

${ }^{4}$ J. Serr, O. Clement, Modlitwa serca, Lublin 1993, s. 55.

5 J. Szyran, Traktat o modlitwie Jezusowej, Warszawa 2016, s. 39.

${ }^{6}$ J. Serr, O. Clement, dz. cyt., s. 12-13. Modlitwa Jezusowa to pewien pomyst na życie: skoncentrowanie wszystkich swoich działań na osobie Jezusa Chrystusa. Docelowo ma prowadzić do modlitwy nieustannej. Sz. Hiżycki, Modlitwa Jezusowa i szczęście czlowieka, http://www.fronda. pl/a/o-hizycki-osb-modlitwa-jezusowa-i-szczescie-czlowieka,93127.html [dostęp 13.04.2018].

${ }^{7}$ Modlitwa Jezusowa, http://www.przystan.krakow.dominikanie.pl/assets/download-files/629 Modlitwa\%20Jezusowa.pdf [dostęp 6.04.2018].

${ }^{8}$ Zob. Mnich Kościoła Wschodniego, Modlitwa Jezusowa, Kraków 1993, s. 7-13.

${ }^{9}$ Por. Modlitwa Jezusowa, dz. cyt.

${ }^{10}$ Pierwsze jest: Stuchaj, Izraelu, Pan Bóg nasz, Pan jest jeden. Będziesz miłowat Pana, Boga swego, catym swoim sercem, cała swoja dusza, calym swoim umystem i cała swoja moca (Mk $12,30)$. 
też przypowieść o tym, że zawsze powinni modlić się i nie ustawać $(Ł \mathrm{k} 18,1)^{11}$. Wskazuje się ponadto na werset Psalmu pięćdziesiątego piątego ${ }^{12}$ oraz na słowa świętego Pawła Apostoła z Listu do Tesaloniczan ${ }^{13}$.

Szukając biblijnych odniesień dotyczących powiązania imienia Boga z modlitwą, można ponadto stwierdzić, iż już w Starym Testamencie imię Boga jest szczególnym elementem tworzącym modlitwę: Uczynisz Mi ottarz z ziemi i będziesz sktadat na nim twoje całopalenia, twoje ofiary biesiadne z twojej trzody i z bydta na każdym miejscu, gdzie każe ci wspominać moje imię. Przyjdę do ciebie $i$ będę ci błogosławit (Wj 20,24). Prorocy zapewniali, że każdy [...], który wezwie imienia Pańskiego, będzie zbawiony (Jl 3,5). Autor psalmu dwudziestego wyznawał wiarę w moc Bożego imienia: jedni wola rydwan, drudzy konie, a nasza siła w imieniu Pana, Boga naszego (Ps 20,8), a w psalmie dwudziestym piątym prosił o odpuszczenie grzechów, powołując się na imię Boże: Przez wzgląd na Twoje imię, Panie, odpuść mój grzech, a jest on wielki (Ps 25,11). Warto zauważyć, iż imię Jezus stanowiło modlitwę niewidomego Bartymeusza, kiedy wołał do Jezusa z Nazaretu: Jezusie, Synu Dawida, ulituj się nade mna (Mk 10,48) ${ }^{14}$, a także ukrzyżowanego z Chrystusem złoczyńcy, kiedy prosił: Jezu wspomnij na mnie, gdy przyjdziesz do swego królestwa (Łk 23,42). Zbawiciel zapewniał o skuteczności modlitwy zanoszonej w Jego imię: Zaprawde, zaprawdę powiadam wam: O cokolwiek byście prosili Ojca, da wam $w$ imię moje. Do tej pory o nic nie prosiliście w imię moje: Proście, a otrzymacie, aby radość wasza była pełna (J 16,23n). Paweł Apostoł polecał czynienie wszystkiego w imię Jezusa, by w ten sposób uczcić Ojca: Wszystko, cokolwiek działacie słowem lub czynem, wszystko (czyńcie) w imię Pana Jezusa, dziękując Bogu Ojcu przez Niego $(\mathrm{Kol} 3,17)^{15}$.

${ }^{11}$ W pewnym mieście żyt sędzia, który Boga się nie bat i nie liczyt się z ludźmi. W tym samym mieście żyła wdowa, która przychodziła do niego z prośbą: „Obroń mnie przed moim przeciwnikiem!” Przez pewien czas nie chciat; lecz potem rzekt do siebie: „Chociaż Boga sie nie boję ani z ludźmi się nie liczę, to jednak, ponieważ naprzykrza mi się ta wdowa, wezme ja w obronę, żeby nie przychodziła bez końca i nie zadręczała mnie”. I Pan dodat: „, Stuchajcie, co ten niesprawiedliwy sędzia mówi. A Bóg, czyż nie weźmie w obronę swoich wybranych, którzy dniem i noca wołaja do Niego, i czy będzie zwlekat w ich sprawie? Powiadam wam, że prędko weźmie ich w obronę. Czy jednak Syn Człowieczy znajdzie wiarę na ziemi, gdy przyjdzie?” (Łk 18,1-8).

${ }_{12}$ Wieczorem, rano $i$ w południe narzekam i jęczę, a głosu mego $[$ On] wystucha (Ps 55, 18).

${ }^{13}$ [...] nieustannie się módlcie! W każdym położeniu dziękujcie, taka jest bowiem wola Boża w Jezusie Chrystusie względem was (1 Tes 5,17-18).

${ }^{14} \mathrm{~W}$ kościołach wschodnich wers ten stał się podstawą tzw. modlitwy Jezusowej.

15 Zob. M. Węcławski, T. Grabowski, Uzasadnienie podniesienia stopnia wspomnienia Najświętszego Imienia Jezus do rangi święta obchodzonego w niedzielę, Poznań - Kraków 3.12.2015, s. 3-4, maszynopis. 
Genezy modlitwy Jezusowej należy szukać w duchowości ojców pustyni, synajskiej, studyckiej oraz atonickiej ${ }^{16}$. Duchowość ojców pustyni ${ }^{17}$ była zróżnicowana, gdyż pustelnicy akcentowali różne aspekty życia duchowego. Niektórzy radzili skupiać umysł w nieustannej pamięci o Bogu, inni bardziej koncentrowali się na ciągłej medytacji wewnętrznej. Ewagriusz wprowadził pojęcie modlitwy czystej, czyli związanej z wyzbyciem się wszelkich myśli i wyobrażeń i wyłącznym skupieniem na Stwórcy. Wszyscy mówili o ascezie, powściągliwości, poście, ale również o roli Ducha Świętego i Jego łaski. Akcentowali także skruchę i żal za grzechy. W końcu egipscy pustelnicy polecali trwanie przy jednej formule i powtarzanie jej głośno lub tylko w myśli, w różnych okolicznościach: przy pracy, posiłku bądź odpoczynku, aby tylko pomagała utrzymać świadomość stałej obecności Boga i wyrażała ufne poddanie się Jego woli ${ }^{18}$.

U mnichów z klasztoru na Synaju dokonało się przejście od życia eremickiego do życia wspólnotowego. Chociaż synajscy mnisi żyli we wspólnocie, nie porzucili ducha pustelniczego, ale dokonała się u nich synteza duchowości Ojców Pustyni i życia wspólnotowego. Do istotnych elementów ich duchowości należy poszukiwanie wewnętrznego wyciszenia (hezychia), traktowanego jako warunek modlitwy i trwania przy Bogu. Poszukiwanie hezychii stało się podstawą życia mniszego. W ten sposób powstał nowy system ascetyczny, rozwijany później na górze Athos, zwany hezychazmem ${ }^{19}$. Według duchowości studyckiej ${ }^{20}$, mnisi zobligowani są - w porównaniu ze świeckimi - wypełniać powinności chrześcijańskie z większym rygorem i zaangażowaniem. Wspólnoty studyckie preferowały

16 Por. Z. Pałubska, Modlitwa Jezusowa, w: Leksykon duchowości katolickiej, red. M. Chmielewski, Lublin - Kraków 2002, s. 549-550. Zob. E. Janasek, S. Koza, Modlitwa Jezusowa w chrześcijaństwie tradycji zachodniej, „Roczniki Teologiczne” t. LIII-LIV, z. 7 (2006-2007), s. 127-143.

${ }_{17}$ Okres ten dotyczy IV-VII wieku, a otwiera go św. Antoni (ok. 251-356). Inni to m.in.: Makary Wielki (300-390), Ewagriusz z Pontu (345-399), Jan Kasjan (360-435), Filemon (IV/V w.), ale także Diadoch z Fotyki (V w.).

${ }_{18}$ Praktyka ta stała się prototypem nieustannej modlitwy serca. Zob. J. Szyran, dz. cyt., s. 2931; A. Kania, Modlitwa Jezusowa, http:/www.katolik.pl/modlitwa-jezusowa,38,416,cz.html [dostęp 12.04.2018].

19 J. Szyran, dz. cyt., s. 33. Hezychazm to nurt duchowości monastycznej chrześcijaństwa wschodniego, który akcentuje rolę modlitwy nieustannej (zwanej także modlitwą czystą, modlitwą serca), w ciągu wieków utożsamioną z modlitwą Jezusową. Szczególny akcent został położony na duchowe doświadczenie (osobiste i świadome przeżycie Bożego daru). Por. E. Fotiju, Hezychazm, w: Leksykon duchowości katolickiej, red. M. Chmielewski, Lublin - Kraków 2002, s. 308-310. Na Synaju rozwinęła się praktyka krótkich wezwań modlitewnych, które były skierowane do Jezusa. Synajską pobożność cechowała subtelna czułość do Boga i serdeczna więź z Chrystusem. Por. J. Szyran, dz. cyt., s. 33. Zob. również Mnich Kościoła Wschodniego, dz. cyt., s. 18-20.

${ }^{20}$ Szczególną rolę dla organizacji życia monastycznego odegrał klasztor zwany Stoudion, który został założony u Złotej Bramy na obrzeżach Konstantynopola. Zaczęto nazywać mnichów tego klasztoru studytami. Już w V wieku klasztor ten strzegł ortodoksji. W tym klasztorze spisano podstawowe prawa i zwyczaje regulujące życie klasztoru, które stały się modelowe dla innych wspólnot monastycyzmu na Wschodzie. Por. J. Szyran, dz. cyt., s. 33-36. 
duchowość o zabarwieniu liturgicznym, aktywnym w świecie i humanistycznym, stanowily miejsce rozwoju mistycyzmu i hezychazmu ${ }^{21}$. W wiekach XIII-XIV głównym ośrodkiem życia duchowego był znany już wcześniej Athos, położony w północno-wschodniej Grecji. W XIV wieku posiadał 25 wielkich zespołów klasztornych, z których część miała formę cenobityczną, a część idiorytmiczną. Na górze Athos znajdowały się także małe domy, w których trzech lub czterech mnichów mieszkało przy ojcu duchownym, a także przebywali eremici. Athos kontynuował tradycje duchowości synajskiej. Tam ostatecznie uformowała się modlitwa Jezusowa, która zdobyła dominującą pozycję w życiu duchowym i stała się sercem wszystkich modlitw. Mnisi na Athos stopniowo ustalali formułę modlitwy Jezusowej, opatrzoną wskazaniem ne varietur, a szczególny nacisk kładli na towarzyszącą modlitwie technikę psycho-fizjologiczną. Athos przez kilka wieków był największym ośrodkiem zakonnym świata chrześcijańskiego, a w największym rozkwicie liczył ponad 40 tysięcy zakonników różnych narodowości ${ }^{22}$.

\section{Glówne elementy modlitwy Jezusowej}

Modlitwa Jezusowa składa się z dwóch części. Pierwsza z nich, czyli $P a-$ nie Jezu Chryste, Synu Boży zawiera wyznanie wiary, uwielbienie i adorację, zakładając osobową więź z Jezusem. Druga część, czyli zmiłuj się nade mna grzesznikiem wyraża skruchę i jest prośbą o miłosierdzie Boga nad człowiekiem. Jej główne elementy są następujące: nieustanna modlitwa, powtarzanie jednego wezwania, specyficzna formuła, moc imienia Jezus, kontemplacja.

Słowa Chrystusa:. Zawsze należy się modlić i nie ustawać (Łk 18,1) oraz świętego Pawła: Nieustannie się módlcie $(1$ Tes 5,17) stanowią podstawę do nieustannego trwania na modlitwie. Regularne odmawianie, prowadzące do modlitewnego stanu (Orygenes, święty Augustyn), dosłownie rozumieli mnisi klasztoru akoimetów w Konstantynopolu oraz niektórzy wędrowni asceci w II połowie IV wieku. Według świętego Bazylego Wielkiego, nieustanna modlitwa to sposób przeżywania obecności Boga, który pozwala kierować ku Niemu wszystkie myśli, słowa i czyny. Należy modlić się w określonych godzinach dnia, ale Boga trzeba też wielbić każdym działaniem, zachowując nieustanną pamięć o Nim. Pierwsi pustelnicy egipscy uważali, iż: Jeżeli [...] mnich modli się tylko wte$d y$, gdy staje do modlitwy, to nigdy się nie modli23. Rozwinęli oni wewnętrzna medytację - ustawiczne rozważanie wybranych słów albo ich recytacja najczę-

${ }^{21}$ Por. tamże.

${ }^{22}$ Obecnie na Athos czynnych jest niespełna dwadzieścia klasztorów, w których przebywa około tysiąc zakonników. Por. tamże, s. 36-39. Zob. także A. Kania, Modlitwa Jezusowa, art. cyt.

23 J. Szyran, dz. cyt., s. 42. 
ściej szeptem lub jedynie w myśli: teksty z Biblii, których uczono się na pamięć, albo powiedzenia ojców, powtarzane w różnych okolicznościach. Szczególnym rodzajem ciągłej medytacji i pamięci o Bogu było częste powtarzanie jednego, niezmiennego wezwania. Taka jedna modlitwa winna stać się spontaniczna i automatyczna. Późniejsi mnisi bizantyńscy zalecali, by jedno wezwanie powtarzać dziesiątki, setki i tysiące razy, aż się do niego przywyknie tak, by wciąż dokonywało się w sercu ${ }^{24}$.

Praktyka krótkich modlitw, często powtarzanych, rozwinęła się w IV-VII w. Zazwyczaj stosowano jeden wers psalmu, werset Ewangelii lub innego tekstu biblijnego, który zawierał prośbę o pomoc czy miłosierdzie, albo też wyrażał uwielbienie Boga. Na Zachodzie to tzw. akty strzeliste (od świętego Augustyna), na Wschodzie tzw. modlitwa jednozdaniowa, monologiczna. Praktyczną metodę pierwszy podał Diadoch z Fotyki w V wieku. Zalecał on powtarzanie krótkiego niezmiennego wezwania, zawierającego imię Jezus. To powtarzanie miało zaspokajać potrzebę aktywności umysłu człowieka, zabezpieczać przed rozproszeniem wielością pojęć i obrazów, pomagać uczynić umysł stałym i skupić się na jednym punkcie. Rozważanie jednej i tej samej formuły pozwala nieustannie odkrywać jej głębię, coraz bardziej przyswajać każde słowo, pomaga też bardziej skupiać się na Tym, do kogo się zwraca ${ }^{25}$. Samo w sobie jest trwaniem w obecności Boga i pomaga nawiązać z Nim silniejsze więzy ${ }^{26}$.

Wezwanie: Panie Jezu Chryste, Synu Boży, zmiłuj się nade mna, grzesznikiem zdobyło szczególne znaczenie i stało się standardową formułą modlitwy Jezusowej. Może być używane w formie krótszej albo mieć nieco inne brzmienie. W sensie ścisłym jednak, modlitwa serca polega na powtarzaniu powyższych słów. Ojcowie pustyni używali różnych wezwań. Jedne stanowiły ufną prośbę o pomoc i zawierały sformułowanie: Wspomóż mnie lub: Broń mnie. Inne natomiast wyrażały skruchę i błaganie o miłosierdzie: Bądź mi litościw, Zmituj się nade mna. Praktykowano i polecano obie formy. Pierwsze formuły, w brzmieniu podobne do standardowej modlitwy Jezusowej, można spotkać w początkach VI w. u palestyńskich mnichów: Barsanufiusza (zm. 540) i Jana (VI w.) oraz Doroteusza (505-565). Panie Jezu Chryste, Synu Boży, zmiłuj się nade mna, po raz pierwszy pojawia się w Żywocie egipskiego mnicha Filemona (prawdopodobnie w VII w.). Dopiero w późnym Bizancjum poświadczone jest dłuższe wezwa-

${ }^{24}$ Por. A. Kania, Modlitwa Jezusowa, art. cyt.; J. Szyran, dz. cyt., s. 40-43.

${ }^{25} \mathrm{C} i$, co kochaja miłościa ludzka, przyrodzona, niemal zawsze maja myśl zwrócona ku przedmiotowi swojej miłości, i serce petne dla niego uczucia, a usta petne wdzięcznych słów i pochwat, podczas nieobecności zaś szukaja tego przedmiotu miłosnymi listami i na każdym drzewie wypisuja jego imię, Tak miłośnicy Boga bezustannie myśla o Bogu i radzi by, gdyby to byto możliwe, na każdym sercu wyryć blogosławione Święte Imię JEZUS. Franciszek Salezy św., Filotea, Warszawa 2003, s. 100 .

${ }^{26}$ Por. J. Szyran, dz. cyt., s. 43-45. 
nie, kończące się słowami: zmiłuj się nade mna grzesznikiem. Formuła ma swoje zakorzenienie w Biblii; chodzi nie tylko o powtarzanie słów, ale o przyjęcie podobnej postawy, która charakteryzowała Bartymeusza ${ }^{27}$, celnika ${ }^{28}$ czy kobietę kananejską ${ }^{29}$. Powtarzanie formuły ma stanowić pomoc w nawiązaniu świadomej i osobowej więzi z Panem ${ }^{30}$.

Istota nieustannej modlitwy polega na tym, że skierowana jest do Zbawiciela. Jej wartość wynika z wiary w moc Imienia Jezus. Imię Jezus obejmuje wszystkie nazwy Zbawiciela: samo imię Jezus znaczy: Bóg zbawia. To imię Boga, który udziela się nam przez wcielenie. Wiąże się z nim tytuł Chrystus, grecki odpowiednik hebrajskiego słowa Mesjasz (Pomazaniec), a więc: wyzwoliciel, zbawca. Tytuł Pan, jaki przysługuje samemu Bogu, do Jezusa był odnoszony zwłaszcza po Jego zmartwychwstaniu. Istotne jest też określenie Syn Boży, którego w ścisłym sensie nie można odnieść do żadnego stworzenia. Wreszcie, Imię Jezus nie różni się od Imienia Bożego i oznacza samego Boga ${ }^{31}$. Modlitwa Jezusowa niekoniecznie musi zawierać słowo Jezus - jest nią każde wezwanie skierowane

${ }^{27}$ Tak przyszli do Jerycha. Gdy wraz z uczniami i sporym tlumem wychodzit z Jerycha, niewidomy żebrak, Bartymeusz, syn Tymeusza, siedziat przy drodze. Ten styszac, że to jest Jezus z Nazaretu, zacząt wołać: „Jezusie, Synu Dawida, ulituj się nade mną!”. Wielu nastawało na niego, żeby umilkł. Lecz on jeszcze głośniej wołał: „Synu Dawida, ulituj się nade mną!”. Jezus przystanął i rzekł: „Zawołajcie go!”. I przywołali niewidomego, mówiąc mu: „Bądź dobrej myśli, wstań, woła cię". On zrzucił z siebie płaszcz, zerwat się i przyszedt do Jezusa. A Jezus przemówił do niego: „Co chcesz, abym ci uczynit?”. Powiedziat Mu niewidomy: „Rabbuni, żebym przejrzat”. Jezus mu rzekt: „Idź, twoja wiara cię uzdrowiła”. Natychmiast przejrzat i szedt za Nim droga (Mk 10, 46-52).

${ }^{28}$ Dwóch ludzi przyszło do światyni, żeby się modlić, jeden faryzeusz, a drugi celnik...[...] celnik stat z daleka i nie śmiał nawet oczu wznieść ku niebu, lecz bit się w piersi i mówit: „Boże, miej litość dla mnie, grzesznika!' Powiadam wam: Ten odszedt do domu usprawiedliwiony, nie tamten. Każdy bowiem, kto się wywyższa, będzie poniżony, a kto się uniża, będzie wywyższony (Łk 18,10-14).

${ }^{29}$ Jezus podażyt w stronę Tyru i Sydonu. A oto kobieta kananejska, wyszedtszy z tamtych okolic, wołała: „Ulituj się nade mna, Panie, Synu Dawida! Moja córka jest ciężko dręczona przez złego ducha". Lecz On nie odezwat się do niej ani stowem. Na to podeszli Jego uczniowie i prosili Go: „Odpraw ja, bo krzyczy za nami!”. Lecz On odpowiedziat: „, Jestem postany tylko do owiec, które poginęły z domu Izraela”. A ona przyszła, upadła przed Nim i prosiła: „Panie, dopomóż mi!'”. On jednak odpart: „Niedobrze jest zabrać chleb dzieciom a rzucić psom”. A ona odrzekta: „,Tak, Panie, lecz i szczenięta jedza z okruszyn, które spadaja ze stołów ich panów". Wtedy Jezus jej odpowiedziat: „, O niewiasto, wielka jest twoja wiara; niech ci się stanie, jak chcesz!”. Od tej chwili jej córka została uzdrowiona (Mt 15,21-28).

${ }^{30}$ Por. J. Szyran, dz. cyt., s. 45-48.

${ }^{31}$ Imię Jezus. O, jak wielkie jest imię Twoje, o Panie, ono jest moca duszy mojej; gdy sity ustaja i ciemności tłocza się do duszy, to imię Twoje jest stońcem, którego promienie oświecaja, ale i grzeja, a dusza pod ich wptywem staje się piękna i promieniuje, biorac blask z imienia Twego. Kiedy stysze najsłodsze imię Jezus, serce mi silniej bije, a sa chwile, kiedy styszac imię Jezus wpadam w omdlenie. Duch mój rwie się do Niego, F. Kowalska, Dzienniczek. Miłosierdzie Boże $w$ duszy mojej, nr 861-862, Warszawa 2016. 
do Chrystusa jako Pana i Syna Bożego. Imię ma w sobie moc obecności Bożej. Samo nie jest tą obecnością, ale ją przywołuje. Przez to imię Chrystus staje się obecny, wchodzi w serce człowieka i czyni z niego swoje mieszkanie ${ }^{32}$.

Poza wzywaniem Imienia Jezus, istotnym elementem tej modlitwy jest skrucha i ukorzenie się, czyli prośba o miłosierdzie. Uznanie swej grzeszności ma prowadzić do pokoju i wolności, stanowić pełne wdzięczności uwielbienie miłosierdzia Bożego, ufność i zdanie się na moc Zbawiciela. Modlitwa Jezusowa wiąże dwa istotne składniki chrześcijańskiej pobożności: adorację i skruchę. Jest ona jednocześnie modlitwą kontemplacyjną: zasadnicza uwaga podczas modlitwy Jezusowej koncentruje się na osobie Chrystusa i przeżywaniu Jego obecności. W najwyższym swym wymiarze, jest to modlitwa kontemplacyjna, właściwie pozbawiona słów (poza wzywaniem Imienia Jezus), podczas której serce człowieka otwiera się na głos Boga i zaczyna doświadczać Jego obecności ${ }^{33}$. Modlitwa ta nie wyklucza medytacji, która może ją poprzedzać ${ }^{34}$.

\section{Etapy modlitwy Jezusowej}

Według wschodniej tradycji, są trzy etapy modlitwy Jezusowej: modlitwa ustna, myślna i serca. Modlitwa ustna to ciągły wysiłek warg, aby powtarzać przyjętą formułę, pod warunkiem, że stan duszy odpowiada treści tego wezwania, że modlący się żyje w pokoju ze wszystkim, zachowuje przykazania, nie trwa w stanie grzechu i jest pokorny. Modlitwa myślna - jest to skoncentrowanie się umysłu na jednym przedmiocie, ponieważ cała uwaga umysłu jest zwrócona na treść wezwania, z jednoczesnym wyzbyciem się wszelkich ubocznych myśli i wyobrażeń. Modlitwa serca może już przebiegać bez wysiłku, samorzutnie, a światło łaski przenika i rozświetla całe wnętrze serca. Tego stanu modlitewnego nie da się wyrazić ludzkimi słowami; jest to przeczucie stanu ostatecznego, kiedy to Bóg będzie wszystkim we wszystkich (por. 1Kor 12,6). Oznacza ona świadome przeżycie obecności Jezusa, spotkanie z Nim w swym sercu, osiągnięcie żywej i osobowej wspólnoty. Aby dojść do tego etapu, trzeba wielkiego wysiłku ascetycznego, doskonałej czystości umysłu, praktykowania cnót.

Ponadto istnieje kolejny stopień, kiedy modlitwa przestaje być rezultatem własnych wysiłków i staje się, przynajmniej na jakiś czas, jak ją określają pisarze

32 Por. J. Szyran, dz. cyt., s. 48-50.

${ }^{33}$ Osiągnięcie modlitwy kontemplacyjnej jest niemożliwe bez ascezy rozumianej jako oczyszczenie myśli oraz zdobywanie cnót. Stąd konieczny jest wysiłek związany z praca nad soba, czyli troską o wierność Bogu, spełnianie przykazań, miłość wyrażającą się w czynach oraz podejmowanie trudu związanego z tak zwaną walką wewnętrzną. Ważna jest także kontrola swoich myśli. Por. J. Szyran, dz. cyt., s. 53.

${ }^{34}$ Por. J. Szyran, dz. cyt., s. 51-54. 
Wschodni, samoczynna (w ujęciu Zachodnim natchniona). Niekiedy się zdarza, że słowa modlitwy stają się mniej ważne lub niemal ustają, a zastępuje je bezpośrednie odczucie Bożej obecności i miłości ${ }^{35}$.

Warto zauważyć, że metoda współcześnie zwana psycho-fizyczna łączy wzywanie Imienia Bożego z instynktownym rytmem ciała. Zawiera trzy elementy: powtarzanie wezwania zespolone jest $\mathrm{z}$ koncentracją na oddychaniu lub nawet może być zharmonizowane z jego rytmem; zalecana jest postawa siedząca, ze schyloną głową i ramionami; wzrok i uwaga skupiają się na określonej części ciała, zwłaszcza na sercu. Owa metoda psychosomatyczna nie jest czystą techniką, ale częścią pewnej całościowej relacji do Chrystusa, zakładającej osobistą więź ze Zbawicielem ${ }^{36}$. Ma ona na celu tylko jedno: ułatwić skupienie, pomóc skoncentrować całą uwagę na słowach: „Panie Jezu Chryste, Synu Boży, zmiłuj się nade mną grzesznikiem" i skierować serce ku Bogu ${ }^{37}$.

\section{Praktyka modlitwy Jezusowej}

Jest wskazanym, dla spełnienia pewnych warunków, by odmawianie modlitwy Jezusowej było możliwie najowocniejsze. Chodzi o warunki ogólne, dotyczące chrześcijańskiej modlitwy, jak i szczegółowe, związane ze specyfiką modlitwy Jezusowej. Ogólne warunki dobrej, chrześcijańskiej modlitwy, to przede wszystkim wewnętrzne wyzbywanie się grzechu, wolność od nieuporządkowanych przywiązań, panowanie nad myślami i wyobraźnią, czysta intencja, świa-

${ }^{35}$ Por. J. Szyran, dz. cyt., s. 53-56.

${ }^{36}$ Medytacja chrześcijańskiego Wschodu docenia symbolizm psychofizyczny, którego często brakowało modlitwie Zachodu. Dotyczyć to może określonej postawy ciała, ale także podstawowych funkcji życiowych, takich jak oddychanie czy bicie serca. Na przykład, ćwiczenie „Modlitwy Jezusa", które odpowiada naturalnemu rytmowi oddychania, może - przynajmniej przez pewien czas - stanowić dla wielu osób rzeczywista pomoc. Z drugiej strony, także ci sami wschodni mistrzowie stwierdzili, że nie wszyscy sa jednakowo zdolni do korzystania z tych symbolizmów, nie wszyscy bowiem sa w stanie przejść od znaku materialnego do poszukiwanej rzeczywistości duchowej. Źle rozumiany symbolizm może nawet stać się idolem $i$ w konsekwencji przeszkoda $w$ podniesieniu ducha ku Bogu. Kongregacja Nauki Wiary, Orationis formas, nr 27, Rzym 1989, w: J. Hadryś, Aby lepiej modlić się, Poznań 2015, s. 96-97.

37 Do dobrej i owocnej modlitwy nie wystarczy jedynie zapewnienie sobie potrzebnego czasu czy też zadbanie o jak najbardziej sprzyjające okoliczności zewnętrzne. Niezbędne jest bowiem usunięcie wszelkich wewnętrznych barier, utrudniajacych spotkanie ze Zbawicielem, oraz rozwijanie pozytywnych postaw, które skutecznie pomagaja w modlitwie, a sq nimi: pokora, ufność i mitość. Oprócz nich można również wskazać na cztery rodzaje czystości, oznaczające pewne postawy niezwykle sprzyjajace owocnej modlitwie, [...] a mianowicie na: czystość sumienia, serca, ducha $i$ działania. Aby modlitwa byta prawdziwie chrześcijańska, potrzeba także regularnego czytania Ewangelii oraz prowadzenia takiego trybu życia, który skutecznie pomoże w podejmowaniu modlitwy. J. Hadryś, Dynamika chrześcijańskiego życia duchowego, Poznań 2017, s. 198, zob. tamże, s. 186-203. 
domość spotkania z Bogiem, żywa wiara, postawa milczenia ${ }^{38}$, a także zadbanie o bezpośrednie przygotowanie się do modlitwy ${ }^{39}$. Warunki związane ze specyfiką modlitwy Jezusowej to zrozumienie sensu formuły, systematyczność, samotność, uciszenie wewnętrzne (uspokojenie), wezwanie Ducha Świętego, niezbyt długi czas modlenia się, czyli tak długo, dopóki modlitwa nie męczy ${ }^{40}$. Zrozumienie sensu formuły jest konieczne, ponieważ modlitwa jest osobowym spotkaniem z Bogiem, stąd nie może być bezmyślnym odmawianiem dłuższej bądź krótszej formuły, ale zakłada świadomość i rozumność w zwracaniu się do Chrystusa. Systematyczność jest niezbędna, gdyż z jednej strony jest już sama w sobie znakiem miłości ku Chrystusowi, a z drugiej pomaga w pamięci o obecności Bożej i wprowadza w praktykę świadomego trwania w niej. Wewnętrzne uciszenie można uznać za warunek wstępny modlitwy Jezusowej, rozpatrując ją od strony osoby modlącej się, natomiast wezwanie Ducha Świętego jest konieczne ze względu na Jego wiodącą rolę w każdej modlitwie, a w Jezusowej w sposób szczególny. Zachowanie odpowiedniego czasu na modlitwę, czyli zadbanie, aby ona nie nużyła, jest uznaniem ograniczoności człowieka i uwzględnieniem jej w modlitewnym spotkaniu z Bogiem, a zarazem obroną przed jej spłyceniem, zniechęceniem czy bezmyślnym odmawianiem.

W praktyce codziennej, szczególnie na początku, należy głośno lub półgłosem wypowiadać słowa Panie Jezu Chryste, Synu Boży, zmiłuj się nade mna, aby wyrobić w sobie nawyk odmawiania takiej modlitwy ${ }^{41}$. Drugim etapem wprowadzenia w modlitwę Imieniem Jezus jest zrozumienia jej treści, a chodzi o to, by

${ }^{38}$ Milczenie (sacrum silentium) jest znane i propagowane $w$ wielu religiach świata, jako wymóg konieczny do zjednoczenia z Bogiem. Człowiek zachowujacy milczenie, odrywa się od zgiełku tego świata i jego spraw, a staje w obliczu Boga, który przemawia w milczacym sercu człowieka; J. Szyran, dz. cyt., s. 19.

${ }^{39}$ Modlitwa przynosi większe korzyści w życiu duchowym wtedy, kiedy jest odpowiednio przygotowana. Przygotowanie to dotyczy zarówno postawy wewnętrznej modlacej się osoby (przygotowanie dalsze), jak i podjęcia działań bezpośrednio poprzedzających modlitwę (przygotowanie bliższe). J. Hadryś, Dynamika chrześcijańskiego życia duchowego, dz. cyt., s. 203., zob. także tamże, s. 203-205. Por. J. Hadryś, Aby lepiej modlić się, dz. cyt., s. 57-66.

${ }^{40}$ Por. Modlitwa Jezusowa, art. cyt. Można tę modlitwę praktykować w każdej sytuacji, na przykład w kaplicy, w kościele, w pokoju, na ulicy, w autobusie, w samochodzie. Trzeba jednak pamiętać, że state zjednoczenie z Bogiem lub wewnętrzne czuwanie i wzywanie pomocy Bożej, które w Nowym Testamencie nazywane jest ,nieustanna modlitwa”, może trwać także wtedy, gdy człowiek - zgodnie z wola Boża - oddaje się pracy i trosce o bliźniego. Poucza nas Apostot: „Przeto czy jecie, czy pijecie, czy cokolwiek innego czynicie, wszystko na chwate Boża czyńcie” (1Kor 10, 31). W istocie, autentyczna modlitwa, jak twierdza wielcy mistrzowie życia wewnętrznego, wzbudza w modlacych się goraca miłość, która przynagla ich do udziału w misji Kościoła i do stużby braciom na wszelka chwatę Boża; Kongregacja Nauki Wiary, Orationis formas, nr 28, dz. cyt., s. $97-98$.

${ }^{41} \mathrm{~W}$ ciągu dnia modlący się miał ją powtórzyć głośno 3000 razy, aby po jakimś czasie dojść do 12 tysięcy. 
Pan Jezus nasycił całą osobę modlącą się, by ją do siebie upodobnił. Na trzecim etapie chodzi o przejście z ust do języka (modlący nie porusza wargami i nic nie powtarza głośno) oraz z języka do serca, czyli do zjednoczenia z Jezusem w miłości. Rytm modlitwy zlewa się wtedy z biciem serca i staje się nieprzerwany. Ten etap oznacza pełnię doskonałości, szczyt modlitwy Imieniem Jezus i bywa często utożsamiany z modlitwą mistyczną. Praktykowanie modlitwy Jezusowej warto podejmować pod kierunkiem kierownika duchownego albo z jakąś grupą, która się wzajemnie wspiera i poszczególni jej członkowie wymieniają między sobą indywidualne doświadczenia ${ }^{42}$.

Warto wiedzieć, iż technika medytacyjna stosowana do modlitwy Jezusowej na górze Athos zawiera wszystkie podstawowe elementy współczesnej medytacji głębi: znalezienie spokojnego miejsca do medytacji; przyjęcie określonej pozycji ciała: nisko usiąść, oprzeć brodę na piersi, zamknąć oczy lub wpatrywać się w serce jako w jeden punkt - centrum - chodzi o skierowanie całej świadomości i uwagi w głąb swojej istoty; sposób oddychania - powolny; pokonanie rozpraszających myśli i wyobraźni; sprowadzenie myślenia z głowy do serca, czyli odmawianie całym sercem i całym umysłem, zharmonizowanie rytmu oddychania z pracą serca; technikę powtarzania, czyli powtarzanie formuły modlitewnej w rytmie wdechu i wydechu, np. Panie, Jezus Chryste - wdech, zmiluj się nade $m n q-$ wydech $^{43}$.

\section{Znaczenie modlitwy Jezusowej}

Podsumowując omawianie zagadnienia modlitwy Jezusowej, można powiedzieć, że modlitwa Jezusowa:

1. Jest trynitarnym wyznaniem wiary. Imię Boga zawiera się w określeniu Pan, Jezus jest wymieniony jako Zbawca, natomiast aluzja do Ducha Świętego opiera się na wypowiedzi Pawła: Nikt też nie może powiedzieć bez pomocy Ducha Świętego: „Panem jest Jezus” (1 Kor 12,3).

2. Wyraża miłość do Chrystusa. Słowa modlitwy są głosem kochającego serca. Pozwalają trwać w zjednoczeniu z Jezusem, uobecniają Go. Jest to pewien rodzaj chrystofanii Zmartwychwstałego Pana, niewidzialnego, nierozpoznawalnego jak kiedyś w drodze do Emaus.

3. Uaktywnia działalność Ducha Świętego. Imienia Jezusa zaczął Kościół pierwotny wzywać po zesłaniu Ducha Świętego. Duch Święty nadaje skuteczność temu Imieniu, gdyż On uobecnia Chrystusa i kontynuuje Jego działalność w Kościele.

${ }_{42}$ Z. Wojciechowski, Modlitwa Imieniem Jezus, http://www.laskawa.pl/sites/default/files/Modlitwa\%20Imieniem\%20Jezus.pdf [dostęp 12.04.2018].

${ }^{43}$ Zob. Modlitwa Jezusowa, art. cyt. 
4. Wprowadza spokój wewnętrzny, radość, ciepło, lekkość. Modlitwa Jezusowa ułatwia panowanie nad sobą, oświeca, pozwala wniknąć w głębię Bożych tajemnic, odsłania sens Pisma Świętego.

5. Sprawia, iż modlący się świadomie trwa w obecności Bożej i otwiera się na zbawczą obecność i zbawcze działanie Zmartwychwstałego Chrystusa. Świadomość Bożej obecności sama w sobie posiada charakter motywujący do życia dla Chrystusa.

Zwieńczeniem refleksji nad teorią i praktyką modlitwy Jezusowej niech będą słowa papieża Franciszka: św. Jan od Krzyża zalecał, by „starać się chodzić zawsze w obecności Boga, rzeczywistej lub wyobrażeniowej albo jednoczącej, stosownie do uczynków, które się spetnia"”. W gruncie rzeczy to pragnienie Boga nie może nie przejawiać się w pewien sposób w naszym życiu codziennym: „, staraj się trwać zawsze w modlitwie i pośród zajęć fizycznych nie zaniedbuj jej. Czy jesz, czy pijesz, czy rozmawiasz, czy obcujesz ze świeckimi, czy cokolwiek innego czynisz, staraj się tak postępować, by pragnać Boga i kierować do Niego uczucia swego serca" 44 .

\section{Jesus' Prayer in theory and practice}

\section{Summary}

The article presents the problem of Jesus' prayer both from the theoretical and practical side. It consists of several parts: an explanation of the concept and validity of this type of prayer, a brief presentation of its history, the transformation of structure, main elements, stages, practice and meaning for spiritual life. The elaboration of the topic was made through analysis and then the synthesis of selected documents of the Church and publications on the Name of Jesus and the prayer with that Name. It was stated, inter alia, that Jesus' prayer is a Trinitarian confession of faith, expresses the love for Christ, enables the activities of the Holy Spirit; brings inner peace, joy, warmth, lightness. Jesus' Prayer eases self-control, enlightens, permits a person to penetrate into the depths of God's mysteries, reveals the meaning of Sacred Scripture, causes the person who is praying to consciously stay in God's presence and to open himself to the saving presence and saving action of the Resurrected Christ. The awareness of God's presence is in itself motivating to live for Christ.

\section{Keywords}

Jesus' prayer, heart prayer, constant prayer, hesychasm

\section{Słowa kluczowe}

modlitwa Jezusowa, modlitwa serca, modlitwa nieustanna, hezychazm

\footnotetext{
${ }^{44}$ Franciszek, Gaudete et exsultate, nr 148, Rzym 2018.
} 


\section{Bibliografia}

\section{Pismo Święte}

Pismo Święte Starego i Nowego Testamentu w przekładzie z języków oryginalnych [Biblia Tysiaclecia], Poznań 2005.

\section{Dokumenty Kościoła}

Franciszek, Gaudete et exsultate, Rzym 2018.

Katechizm Kościoła katolickiego, Poznań 2002.

Kongregacja Nauki Wiary, Orationis formas, Rzym 1989, w: J. Hadryś, Aby lepiej modlić się, Poznań 2015, s. 81-99.

\section{Literatura przedmiotu i pomocnicza}

Fotiju E., Hezychazm, w: Leksykon duchowości katolickiej, red. M. Chmielewski, Lublin - Kraków 2002, s. 308-310.

Hadryś J., Dynamika chrześcijańskiego życia duchowego, Poznań 2017.

Hiżycki Sz., Modlitwa Jezusowa i szczęście człowieka, http://www.fronda.pl/a/o-hizycki-osb-modlitwa-jezusowa-i-szczescie-czlowieka,93127.html [dostęp 13.04.2018].

Hadryś J., Aby lepiej modlić się, Poznań 2015.

Janasek E., Koza S., Modlitwa Jezusowa w chrześcijaństwie tradycji zachodniej, „Roczniki Teologiczne" t. LIII-LIV, z. 7(2006-2007), s. 127-143.

Kania A., Modlitwa Jezusowa, http://www.katolik.pl/modlitwa-jezusowa,38,416,cz.html [dostęp 12.04.2018].

Kowalska F., Dzienniczek. Miłosierdzie Boże w duszy mojej, nr 861-862, Warszawa 2016.

Modlitwa Jezusowa, http://www.przystan.krakow.dominikanie.pl/assets/download-files/629_Modlitwa\%20Jezusowa.pdf [dostęp 6.04.2018].

Mnich Kościoła Wschodniego, Modlitwa Jezusowa, Kraków 1993.

Pałubska Z., Modlitwa Jezusowa, w: Leksykon duchowości katolickiej, red. M. Chmielewski, Lublin - Kraków 2002, s. 549-550.

Salezy Fr., Filotea, Warszawa 2003.

Serr J., Clement O., Modlitwa serca, Lublin 1993.

Szyran J., Traktakt o modlitwie Jezusowej, Warszawa 2016.

Węcławski M., Grabowski T., Uzasadnienie podniesienia stopnia wspomnienia Najświętszego Imienia Jezus do rangi święta obchodzonego w niedzielę, Poznań - Kraków 3.12.2015, maszynopis.

Wojciechowski Z., Modlitwa Imieniem Jezus, http://www.laskawa.pl/sites/default/files/Modlitwa\%20Imieniem\%20Jezus.pdf [dostęp 12.04.2018]. 